\title{
Building Eurafrica: Reviving Colonialism through European Integration, 1920-1960
}

\author{
Peo Hansen \& Stefan Jonsson \\ Linköping University (peo.hansen@liu.se) (stefan.jonsson@liu.se) \\ Paper Presented at the EUSA Twelfth Biennial International Conference \\ Boston, March 3-5, 2011 \\ Panel 8F Historiography and History Politics in European Integration \\ Chair: Jan Ifversen, Aarhus University
}

\begin{abstract}
This paper examines the history of the 'Eurafrican project' as it evolved from the PanEuropean movement in the 1920s to its institutionalization in the European Economic Community (EEC) (i.e. today's EU) in the late 1950s. As we show, practically all of the visions, movements and concrete institutional arrangements working towards European integration during this period placed Africa's incorporation into the European enterprise as a central objective. As so much of the scholarly, political and journalistic accounts at the time testify to, European integration was inextricably bound up with a Eurafrican project. According to the intellectual, political and institutional discourse on Eurafrica-or the fate of Europe's colonial enterprise-a future European community presupposed the transformation of the strictly national colonial projects into a joint European colonization of Africa. There is strong evidence to support that this project was instrumental in the actual, diplomatic and political constitution of the EEC, or of Europe as a political subject. According to our thesis, the origins of the EU cannot be separated from the perceived necessity to preserve and reinvigorate the colonial system. On a second level the paper also introduces a broader historiographic problematic in which we position Eurafrica as the wider but by now forgotten formation that shaped Europe and Africa and their relations to one another in the greater part of the twentieth century. Eurafrica conditioned both the integration of Europe and the political landscape in postcolonial Africa. We are thus able to shift the terrain upon which most if not all scholarly analyses of the political, economic and ideological developments on the two continents have taken place up until now. Eurafrica is the forgotten geopolitical context that must be reconstructed in order for us to resolve a set of crucial historical and political problems. Questioning the historical framework usually employed in EU studies, our intervention emphasizes the radically different geopolitical designs for the postwar world order that was encoded in the Eurafrican project. Finally, we also show how these Eurafrican designs continue to influence current relations between Europe and Africa.
\end{abstract}




\title{
Building Eurafrica: Reviving Colonialism through European Integration, 1920-1960
}

\author{
Peo Hansen \& Stefan Jonsson
}

\begin{abstract}
'Er [der Bundesminister für Wohnungsbau] unterstütze daher den Vorschlag, daß Europa gemeinsam in dem afrikanischen Kontinent Fuß fasse. Die Aktion müsse unter dem Schlagwort „Europa baut für Afrika“ stehen. Die Beteiligung der europäischen Gemeinschaft sei nicht nur nötig, sondern auch überfällig. Wir dürfen diese Position nicht räumen.' (Kabinettssitzung, Bundesregierung, 16 January, 1957, p. 101)

[Bundeskanzler Adenauer:] 'Die Schwarzen bedürfen noch immer gewisser Lenkung. ... Im Ergebnis sei es ein Segen für die Schwarzen, wenn wir uns an der Erschließung der Gebiete beteiligen.' (Kabinettssitzung, Bundesregierung, 16 January, 1957, p. 101)

'Sodann spricht der Bundeskanzler über die gestrige Zusammenkunft der Regierungschefs der Montanunion-Staaten in Paris [February 20, 1957]. Der Bundeskanzler knüpft an einen Zeitungsartikel an, der von der "Vision von Eurafrika“ spricht. Alle großen Ideen erschienen zunächst visionär, so auch die enge Verbindung zwischen Europa und Afrika und die enge wirtschaftliche Verbindung zwischen den Montanunion-Staaten, die jetzt beginnen solle. Keine über das Tagesgeschehen hinausgehende Tätigkeit sei in der Welt ohne Risiko. Dieses Risiko müsse das frei Europa auf sich nehmen, um nicht in absehbarer Zeit zwischen den Völkern Asiens und Afrika erdrückt zu werden, wenn diese Völker gegenüber Europa eine feindliche Haltung einnehmen sollten.' (Kabinettssitzung, Bundesregierung, 21 February, 1957, p. 155)
\end{abstract}

Scholarship on the history of European integration often points to the experience of and fight against the 'Nazi horror' as key catalysts for amplifying a sense of European solidarity and identity that in turn helped pave the way for the postwar movement towards European integration. 'The more plainly the totalitarian character, contempt for legality, and racial arrogance of Nazism were shown in action', the late Nestor of European integration history Walter Lipgens (1982: 46) writes, 'the more people came to their senses and returned to the true European tradition.' What has gone unnoticed in this extensive scholarship though, is the fact that a few decades prior to the Nazi collapse another 'true European tradition', namely 'racial arrogance' itself, helped galvanize European solidarity in the fight against another 'horror'. The perceived horror 
consisted of the tens of thousands of colonial troops deployed by France for the occupation of the German Rhineland following Germany's defeat in the First World War. Numerous leaders, popular movements and media outlets across Europe and beyond referred to this 'abomination' as the 'Black horror on the Rhine' (Nelson 1970; Lusane 2003; Wigger 2010). In Mein Kampf (first published in 1925) Hitler spoke of the colonial troops in terms of 'the contamination by Negro blood on the Rhine in the heart of Europe [...] bastardizing the European continent at its core' (quoted in Lusane 2003: 80). Hitler was certainly in good company, similar opinions reaching well into Western Europe's liberal and social democratic establishments, as well as into prominent women's organizations (Nelson 1970; Lusane 2003).

For our purposes here, the most important aspect of the 'Black horror' relates to its place in the early modern history of European integration, commencing in the interwar period and culminating in the signing of the Treaty of Rome in 1957, which gave birth to the European Economic Community (i.e. today's European Union). As we will go on to demonstrate, by situating it in this context, the widespread fury unleashed by the presence of colonial troops in the 'heart of Europe' can serve as a wedge that discloses the intimate yet neglected bond between European integration, on the one side, and colonialism and African colonies in particular, on the other. ${ }^{1}$ Indeed, from the interwar period up until the late 1950s practically all of the visions, movements and concrete institutional arrangements working towards European integration placed Africa's incorporation into the European enterprise as a central objective. As so much of the

\footnotetext{
${ }^{1}$ For more on this neglected bond, see Muller (2000) and Moser (2000).
} 
scholarly, political and journalistic accounts at the time testify to, European integration was inextricably bound up with a Eurafrican project. At the Hague Congress of Europe in 1948, for instance, it was proclaimed that 'The European Union must, of course, include in its orbit the extensions, dependencies and associated territories of the European Powers in Africa and elsewhere, and must preserve the existing constitutional ties which unite them.' (quoted in Hick 1991a: 335-6) ${ }^{2}$ Nine years later, French socialist premier Guy Mollet, upon the conclusion of the negotiations for the Treaty of Rome which established the European Economic Community (EEC), stated as follows at a press conference in Washington DC:

I would like to insist upon the unity of Europe: it is now a fact. A few days ago we jumped over the last hurdles that were on its way, and now an even broader unity is being born: EURAFRICA, a close association in which we will work together to promote progress, happiness and democracy in Africa. (File: EN2737, 25 February 1957, Mollet, Historical Archives of the European Union [HAEU])

In this sense, as the former Secretary of the Council of Europe's Economic Committee, U. W. Kitzinger (1960: 31) stated a few years later, 'For the new French government the [European] Economic Community was in fact a Eurafrican as much as a European scheme.'

\footnotetext{
${ }^{2}$ The Congress of Europe in The Hague gathered some 750 delegates and political leaders (including Konrad Adenauer and Winston Churchill), representing various interests, movements and parties (excluding the communists and the far right). It was organized by the International Committee of the Movements for European Unity and gave birth to the European Movement and subsequently, in 1949, the Council of Europe.
} 
In his magnum opus Europe: A History, Oxford historian Norman Davies is thus as dead wrong as he is archetypal of today's prevailing attitude when he claims that '[d]ecolonization was a necessary precondition for the emergence of a new European Community of equal, democratic partners.' (Davies 1996: 1068) In fact, it was the exact other way around, or as Irwin Wall (2001: 77) puts it: 'Neither the construction of Europe nor the building of a French nuclear deterrent was conceived of or understood in Paris as a substitute for a moribund colonialism, as several historians have argued. On the contrary, both were meant to provide the means of maintaining France's Eurafrican hegemony.'

Much of mainstream EU studies have yet to cast off the whiggish approach to the history of European integration (Gilbert 2008), too often positing European integration as imbued with a benevolent historical purpose, much like nationalist intellectuals' refusal in earlier periods to critically scrutinize the historical origins of national projects. By charting European integration's Eurafrican history we wish to sketch the contours of what we take to be a new framework for the study of European integration history.

\section{The 'Black Horror on the Rhine'}

More than a million soldiers born in the colonies of the European states fought on European battlefields in the First World War, almost all of them on the French and the British sides (Koller 2001: 87-102). In the French troops that after the war continued 
the occupation of the Rhineland, there were between 20,000 and 45,000 of soldiers from Madagascar, West Africa, Morocco and Algeria (Lusane 2003: 72).

The presence of non-white soldiers in the occupying forces bred strong emotions among the Germans and the wider European public and intelligentsia. African soldiers were generally perceived as unreliable savages, who posed great danger especially for the German female and juvenile population (Wigger 2010). Talk about 'the black horror', 'the black disgrace', 'the black shame' and 'the black peril' was in everybody's mouth. When Germany's Reich chancellor Müller, the highest ranking politician of the nation and a social democrat, addressed the parliament in April 1920 he started by stating the unbelievable: 'French militarism has marched across the Main as into enemy country'; and then went on to state the unthinkable: 'Senegal negroes are camping in the Frankfurt University, guarding the Goethe House.' (quoted in Koller 2001: 213) This was the scandal: Goethe, the very monument of the European spirit, the very proof of German superiority, now soiled and disgraced by black hands.

The First World War ended with Germany's dishonourable concession of defeat and the ensuing peace treaties of Versailles and Trianon. In order to ensure Germany's payment of its war debts French troops in 1923 assumed control of the Ruhr area, the most vital industrial zone in mainland Europe. This time, the share of colonial troops was small. This did not prevent German politicians and moulders of public opinion from feeling humiliated and even violated. Germany's president, social democrat Friedrich Ebert, repeatedly stated his conviction that 'the deployment of coloured troops of the most inferior culture as overseers of a population of such high spiritual and economic 
importance as the Rhinelanders is an intolerable violation of the law of European civilization.' (Ebert 1926: 290, quoted in Koller 2001: 324)

Ebert's opinion was indeed shared by all political parties in Germany of the period, with the exception of communists and independent social democrats. Visual images of the period illustrate that Germany regarded the presence of black and coloured troops as a humiliation so shameful that it rocked at the very foundation of national identity. One poster from 1920 shows a happy-looking black man, all naked except for the helmet usually worn by French troops, standing like a huge colossus with his legs spread wide and his giant feet crushing the cross-framed houses of a German town, at the same time rubbing against his waist and sexual organ ivory-white female bodies that he has caught in his hands (Theweleit 2000: 1001). Yet another illustration is a commemorative coin, minted and sold to promote resistance against the French occupation. At one side of the coin is the facial profile of a black soldier, caricatured to look like a monkey, next to which are stamped the words "Liberté, Egalité, Fraternité" and "Die Wacht am Rhein", "Guard on the Rhine." On the other side of the coin we see a woman tied to a tree, the trunk of which, at closer scrutiny, turns out to be an enormous erected penis.

\section{Configurations of Eurafrica in the Interwar Period}

In one sense, these statements and images are just a continuation of a long history of Europe's racial stereotyping of non-European peoples. Our reason for returning to 
them now, however, is that they are also repressed parts of the origin and beginning of a new history: the history of European integration. For it is in this area and in this period that the story of what is today known as the European Union (EU) can be said to begin. This is for many reasons. A first, more anecdotic yet nonetheless significant reason is that Konrad Adenauer, the West German prime minister who was instrumental for European integration after the Second World War, resided as vice mayor and mayor in Cologne during the whole Weimar period from 1919 to 1933. Adenauer's political world-view was largely shaped by the conflicts in the Rhineland during and after the First World War, but also by what Adenauer took to be the very regrettable loss of Germany's African empire (Schwartz 1995: 95-6). Another reason, as we shall see, is that the emergence of the European integration project is far more intimately connected to Africa and to the question of Europe's dominance over Africa than we are led to believe by standard works on the history of modern Europe. Thirdly, for those who first asserted the necessity of a European Union, it was precisely this geographic area, the Rhineland and the Ruhr region - or the border zone between France and Germany and between Germany and the Benelux countries - that showed both the crux and proof of their argument. We have already mentioned that France's decision to march across the Ruhr and the Rhine with colonial troops turned Germany's political emotions to boiling. However, smaller and soon larger groups of intellectuals reached the opposite conclusion. In their view, France's occupation of the Ruhr only demonstrated that the age-old animosity between France and Germany had led both states into a dead end. In 1923, Richard Coudenhove-Kalergi published his pamphlet 
Paneuropa. For him, too, the Ruhr occupation and the apparently irresolvable border conflict between France and Germany were causes of alarm. In order to prevent these once so powerful European states from being squashed between the growing powers to the east and the west, the states of Europe must unite in a Pan-European union; and the first step in this process, Coudenhove-Kalergi ([1923] 1926: 107-22) argued, must be taken by France and Germany.

Coudenhove-Kalergi's pamphlet contains roughly the same argument, but elaborated in greater detail, as did many other proposals for European collaboration presented during the 1920s. "After 1923 whole staffs of periodicals, associated pressure groups in many countries, and at least two dozen books published every year pursued this aim", writes Walter Lipgens (1982: 38). According to Lipgens, Coudenhove-Kalergi's Paneuropa was by far the most important of these initiatives. To be sure, this CzechAustrian thinker, brought up in the Habsburg Empire and inspired by its supra-national constitution, did not devote himself only to thinking and writing, but also organized a huge Pan-European movement that gathered influential intellectual and political support from the best and the brightest of his generation, including the brothers Heinrich and Thomas Mann, as well as statesmen like Winston Churchill, Konrad Adenauer and Aristide Briand, the latter serving for a long time as chairman of the PanEuropean Union.

Coudenhove-Kalergi's argument for a European union mirrors the world view of internationalists and liberal progressives of his era. A united Europe was paramount for political reasons, or simply to prevent a repetition of the First World War. This was the 
argument for peace. A united Europe was desirable also for cultural reasons, as history seemed to indicate that Europe was a spiritual unity owning a specific Weltanschauung. This was the argument for civilization. In addition, the 1920s added a third, economic argument; for as Europeans compared their own states to the rapidly growing economies of the United States and the Soviet Union, they concluded that both enjoyed the advantage of being able to organize their economies on a continental scale, whereas Europe was politically divided and suffered economically from numerous trade barriers. This economic perspective then gradually turned into a geopolitical one, which touched the sensitive issue as to whether Europe would be able to regain its place as a dominant power on a par with the other ones. From this perspective, Africa was seen as a natural or necessary part of Europe's geopolitical sphere, a part that needed to be more strongly connected to Europe, and one that needed to be exploited by united European forces in order to be properly and adequately used. As the intellectuals of the 1920s argued in favour of a European union or federation, their arguments implicitly or explicitly addressed Africa. Europe could develop its fullest economic and political potential only through Africa.

Africa was mainly looked upon as a great provider of natural resources and agricultural produce, but also as a reservoir for hydroelectric power. Sometimes, Africa also was seen as the solution to Europe's demographic problems; it was widely agreed that Europe was overpopulated, and the continent would be greatly helped if surplus population could emigrate and settle in the 'empty' territory south of the Mediterranean. As Coudenhove-Kalergi (1929: 3) stated in his essay 'Africa': 'Africa 
could provide Europe with raw materials for its industry, nutrition for its population, land for its overpopulation, labour for its unemployed, and markets for its products.'

What is important is that all these arguments for an assimilation of Africa into Europe then formed yet another strong argument for the unification of Europe. The common or synergetic exploitation of Africa appeared as an aim so unquestionable, so attractive and beneficial, that it in itself would be a reason for the European states to make common cause. A geopolitical calculation emerged in which two good things reinforced one other: by uniting Europe a new geopolitical sphere would emerge that thanks to its inclusion of Africa would be sustainable and prosperous; and by together developing Africa the bonds would grow stronger between once antagonistic European states. A unification of Europe and a unified European effort to colonize Africa were two processes that presupposed one another. As Coudenhove-Kalergi (1929: 18) wrote: 'The African problem thus brings us back to Europe. Africa cannot be made available, if Europe does not unite.'

This argument won support especially in Germany, which, through an arrangement of this kind, would regain access to its former colonial territories that it had lost in the First World War (see e.g. Coudenhoven-Kalergi 1932: 7-11). Interwar politicians and intellectuals also gave a name to the new great power that would again raise the star of Europe. The geopolitical bloc was called Eurafrica, a notion so prevalent in these years that it is difficult, if not impossible to find out who actually coined it (see Ageron 1975). Contrary to a common understanding and standard historiography of the roots of today's European Union - in which Coudenhove-Kalergi is seen as the father figure of 
the founding fathers - Pan-Europe was not a project limited to Europe alone, but one which included Africa in its entirety, except for its British possessions. A related geopolitical blueprint was drawn up by Hermann Sörgel (1932). All European nations, he suggested, should unify in the common task of damming the entire Mediterranean Sea, thus attaching Africa to Europe, providing the depressed European economy with vital resources and the white race with indispensable 'Lebensraum'.

Another influential exponent of this geopolitical theory is E. L. Guernier, Frenchman and author of numerous works on colonialism, among them L'Afrique - Champ d'expansion de l'Europe from 1932. In the preface of his book, Guernier remarks that there is now a new kind of colonialism (1933: vii): 'Today's colonization is the synthesis of a moral and highly civilizing endeavour - the gradual elevation of the standing of life of the non-developed races - and the no less human endeavour of the continuous maintenance, if not improvement of the conditions of life of an industrious Europe.' Guernier asserts that both continents stand to benefit from a thorough unification. Europe offers to Africa morality, culture, and civilization. Africa offers Europe raw materials, territory, resources, or, in short, opportunities for investment and growth. The result of Europe's expansion in Africa is not just the unification of Europe, but the emergence of a third geopolitical power-sphere that creates an equilibrium in the global world system. For Guernier, as for Coudenhove-Kalergi, Sörgel and others, the unification of Europe and the colonization of Africa, are projects that presuppose one another. Guernier's plan was published in the wake of the great Colonial Exposition in Paris in 1931. All colonial powers except for Britain were here invited to display their 
colonial possessions - including native inhabitants - in the Vincennes forest near Paris. Top-ranking French politicians such as Paul Reynaud, minister of colonies, and Hubert Lyautey, former governor general of Morocco, argued that the European collaboration at the exposition must now be followed by a co-European collaboration in the colonies themselves, 'for which France was prepared' (Ageron 1975: 461). Lyautey called for a 'union of all the colonizing nations in a policy of association for the greater moral and material profit of all' (quoted in Morton 2000: 314).

We could go on mentioning a number of other works containing similar arguments. However, none of these suggests that there is any symmetry between the two halves, much less any equality. 'Africa is the only continent without history', writes Guernier (1933: 55), after which he goes on to show what Europeans must and should do in order to have primitive and isolated Africa enter the circle of human culture. As for Coudenhove-Kalergi, justifiably known as pacifist, internationalist and anti-Nazi, he comes across as a full-fledged biological racist when he speaks about Africa, claiming that there are inherent differences between the black and white races. 'As long as the black race is unable to develop and civilize its part of the earth, the white race must do it.' At the same time, he states that Europe must at all costs prevent 'that great numbers of black workers and soldiers immigrate to Europe' (Coudenhove-Kalergi 1929: 5).

We must note here that Coudenhove-Kalergi speaks of soldiers. He is probably thinking of France's disputed use of black troops in its occupation of the Rhineland. For just as unthinkable as it was having black soldiers operate as law keepers and masters 
of German towns, just as self-evident it was to have European physicians and engineers developing Africa. Coudenhove-Kalergi (1929: 5) asks what would become of Africa if Europe pulled out from it: 'The answer is: chaos, anarchy, misery, war of all tribes against one another.'

This is where we are able to locate the deep structure of the interwar discourse on Eurafrica. It is a racist discourse that allows its user to reject African presence in Europe as an absurdity with the same ease as he affirms European presence in Africa as a necessity, without even having to consider the possibility that the position is selfcontradictory.

\section{Postwar Institutionalizations of Eurafrica}

All of the above may strike some readers as anecdotal history with little relevance to the present world order. However, after the Second World War Eurafrica was revived, developed and institutionalized as a primary aim for many European politicians, institutions, intellectuals and organized interests. Immediately after the war's end, Britain's foreign secretary Ernest Bevin (Labour) launched his bid to establish a 'Third World Power', working to integrate particularly the African colonies and their vast natural resources into a Western European power sphere able to withstand a world order dictated by the US and the Soviet Union. Built on the close colonial cooperation 
between Britain and France, ${ }^{3}$ such a scheme, Bevin believed, 'could have the US dependent on us and eating out of our hands in four or five years ... [the] US is barren of essential material and in Africa we have them all.' (quoted in Deighton 2006: 845) As Ann Deighton (2006: 836-9) aptly elucidates, Bevin's Third World Power enterprise was firmly rooted in the interwar period's Eurafrican current of ideas.

For all the instances of ideational continuity though, the postwar period distinguishes itself through its institutionalization and thus operationalization of the Eurafrica conception. Perhaps the first instance of this took place within the framework of the Organisation for European Economic Co-operation (OEEC, subsequently the OECD), formed in 1948 for the purpose of administering the US Marshall Plan - or the European Recovery Program. While portions of its funds were used to assist individual recipient states in their work to boost financial stability in their respective colonial empires (OEEC 1951: 51, 75; Lynch 1997: 192), the OEEC immediately decided to form an Overseas Territories Working Group in order to promote European cooperation in colonial affairs, particularly towards Africa. In its extensive report from 1951 the OEEC (1951) stated that the necessary public and private investment in overseas territories by no means should be limited to Europe's colonial powers, but that all members should be encouraged to contribute: 'It is in the interest of the whole free world that the [colonial] territories, which form part of it, should endeavour to speed up and increase the production of scarce materials.' (OEEC 1951: 20) Although formulated in less grandiose and utopian terms, the report echoes the interwar period's plans for

\footnotetext{
${ }^{3}$ For a detailed account of the many, but mostly frustrated attempts to institute Franco-British colonial cooperation in Black Africa in the first postwar decade, see Kent (1992).
} 
Eurafrica in its focus on large-scale infrastructural projects, water control, agriculture and 'constructional work, on a heavier scale'; e.g.: 'Vast stretches of mosquito-infested swamp must be drained.' (OEEC 1951: 21) What is more, the report is totally void of indications that colonialism in Africa might some day come to an end; on the contrary Eurafrican planning is unreservedly described as 'a long-term task' in an African terrain characterized by 'political security' (OEEC 1951: 72).

Whereas NATO, founded in 1949, would contain a minor Eurafrican outfit through its incorporation of France's Algerian departments, at the ultimative request of Paris and against US aspirations, it was the Council of Europe (CE), also established in 1949, that would take the Eurafrican scheme to the next level. The CE grew out of the European Movement and its Congress of Europe held in The Hague in 1948. As indicated above, most of the Congress' participant groupings (among them Coudenhove-Kalergi's new organization, the European Parliamentary Union) adhered to the Eurafrican tenet concerning the imperative necessity of developing African colonies for the collective benefit of a war-torn Western Europe striving to emerge as a 'third force' in world politics (see further Palayret 2005). 'If we wish to rebuild', said Hendrik Brugmans of the European Union of Federalists (EUF), 'we urgently need "living space" - if you will forgive the expression - on a bigger scale than that of the old, so-called autonomous nations.' (quoted in Hick 1991b: 16) In its 'Draft of a Federal Pact', the EUF went on to proclaim: 
Europe as an entity will be viable only if the links which unite it with countries and dependent territories [...] are taken into account. The era of national ownership of colonial territories is past. [...] From now onwards a common European policy of development for certain regions of Africa should be taken in hand (quoted in Hick 1991b: 90).

While the Council of Europe (CE) failed entirely to embody the federal principles advocated by most parties at the Congress of Europe, it immediately succeeded in turning Eurafrica into one of the organization's defining priorities (see Palayret 2005: 200-213; Heywood 1981), a fact largely forgotten today. The unanimous adoption of the 'Strasbourg Plan' by the CE's Consultative Assembly in 1952 provides ample testimony to the Eurafrican momentum during the 1950s. Built on an extensive expert report by the Consultative Assembly's Secretariat-General as well as the work within the OEEC, the Plan set out to resolve one of Western Europe's most pressing problems at the time, namely its chronic and paralyzing dollar deficit, which the by now discontinued Marshall aid had done little to settle. The answer? Africa! As German representative Johannes Semler, heading the CE's Committee on Economic Relations with Overseas Territories, pleaded for the Plan before the Assembly, he quoted from a speech made a week earlier by former French prime minister Paul Reynaud, now chairman of the CE's Committee on Economic Questions:

We must also, if free Europe is to be made viable, jointly exploit the riches of the African continent, and try to find there those raw materials which we are getting 
from the dollar area, and for which we are unable to pay. (quoted in CE 1952: 135)

In so doing, this would facilitate Western Europe's transition into 'a third economic group standing mid-way between the Communist and the dollar areas' (CE 1952: 15). However, since the large-scale investments required could not be shouldered by the colonial powers alone, the Plan was adamant in stressing the indispensability of all Council members (by now 14 countries) contributing. As pointed out by the UK representative Lord Layton, 'it is clear that we have to think of these overseas territories not as the possessions of any one country [...]; they have to be integrated with all the countries of Europe and all the overseas territories' (CE 1952: 140). This chimed with practically all of the representatives. For instance, Denmark's Hermond Lannung emphasized 'the overriding importance of greater co-operation and of a major joint European effort in Africa if we do not wish to see Africa lost to European influence, culture, trade, etc., and, in the long run, for that influence to be replaced by that of another continent.' Europe had just lost the 'battle of Asia', Lannung asserted, and now its nations needed to unite in order to not also lose 'the battle of Africa'. 'Here we have before us a great concrete and practical task which calls for the utmost collaboration of us all.' (CE 1952: 154)

For this project to become viable, obviously, West German, but also Scandinavian, capital and industrial clout was greatly sought after (CE 1952: 54-7; 175; 190). According to the expert report, all parties stood to gain from such a collaborative approach: 'If European countries without colonial responsibilities contribute to the 
development of overseas territories it will then be possible to open these overseas markets to them.' (CE 1952: 64) With limited access to its traditional markets in the east - now within the Soviet orbit of control - the report argued, such a scenario should provide West Germany, in particular, with an important incentive to look to Africa as an outlet for its 'tractors, cranes, bridges, dredges, machine tools, etc.' (CE 1952: 54) As during the interwar's Eurafrica debate, the topic of European emigration to Africa also figured prominently in the Strasbourg Plan, since 'over-population' still was seen as 'one of Europe's most critical human and social problems' (CE 1952: 58).

On the 9th of May 1950, almost exactly a year after the establishment of the Council of Europe, French foreign minister Robert Schuman presented what was to become known as the Schuman Declaration or Schuman Plan, announcing the Franco-German aim to jointly regulate extraction and production of coal and steel. The Schuman Plan gave birth to the European Coal and Steel Community (ECSC) in the Treaty of Paris a year later, comprising France, West Germany, Italy and the Benelux countries. The ECSC not only created a common market for coal and steel amongst the six members, but most significantly and symbolically it also vested the control over production with a supranational High Authority. With coal and steel constituting the basis for arms production, this arrangement was primarily designed so as to tie France and West Germany together, or as it was stated in the Schuman Plan: 'The solidarity in production thus established will make it plain that any war between France and Germany becomes not merely unthinkable, but materially impossible.' (European 
Union 2009a) Due to its peace message and supranational design, the Schuman Plan, and not least Robert Schuman himself, is a darling within today's EU policy parlance and the whiggish EU scholarship. Since 1985, moreover, the EU officially celebrates the 9th of May as 'Europe Day' in the spirit of 'peace and solidarity' (European Union 2009b), no mention being made, of course, of the fact that while Robert Schuman made his 9th of May plea for 'World peace', France fought an extremely brutal colonial war in Indochina.

As for Eurafrican institutionalization, the ECSC offered little on paper, but the Schuman Declaration itself spoke in more assertive terms: 'With increased resources Europe will be able to pursue the achievement of one of its essential tasks, namely, the development of the African continent.' (European Union 2009a) The immediate mastermind behind this formulation, according to McKay (1963: 139), was no one less than the 'Father of Europe' himself, Jean Monnet, also the chief architect of the ECSC and a keen Eurafricanist (see further Hurd 1957). Apparently, Schuman had picked up on Monnet's suggestion that France could give Africa as a "'dowry to Europe"' (quoted in McKay 1963: 139). As such, the Schuman Declaration's Eurafrican passage follows from the historical pattern sketched above. Since the 1920s, community and collaboration of Europe's states had presupposed their collaboration in Africa as well. Now, as both the Council of Europe and the ECSC were established, their protagonists obviously felt it important to signal that these institutions of European integration enabled the more far-reaching collaboration that had for long occupied debates on foreign policy and geopolitics. Many European intellectuals picked up the signal, among 
them influential German writer on foreign policy, Anton Zischka. In his view, the Franco-German coal and steel agreement was but the first step in a process leading to a common exploitation of Africa's resources. Africa, argued Zischka (1951) in the title of his book, was 'Europas Gemeinschaftsaufgabe Nr. 1' ('Europe’s number one common priority').

As we enter the period for the Rome Treaty negotiations (1955-1957) and their culmination in the establishment of the European Economic Community (EEC), Eurafrica would emerge as the issue upon which the final stages of the negotiations would hinge (see e.g. Guillen 1992; Laurent 1972; Lynch 1997). Indeed, it seems safe to say that there would not have been an EEC/EU, at least not at this juncture in time, had it not been for the German and Dutch governments' decision to submit to the French ultimatum (supported by Belgium and, eventually, Italy) to incorporate into the EEC not only France's departments in Algeria, but also to associate with the Community all of the member states' colonial possessions: French West and Equatorial Africa, Belgian Congo and Ruanda-Urundi, Italian Somaliland and Netherlands New Guinea. As spelled out in the Rome Treaty, the purpose of colonial association was 'to promote the economic and social [and cultural] development of the countries and territories and to establish close economic relations between them and the Community as a whole' (see further Treaty establishing the European Economic Community 1957: Arts. 131-6; 227; Annex IV). As part of this, a European Development Fund was established (still in place today) to which all members contributed - West Germany and France being the largest providers - but from which, of course, French colonies by far benefitted the most. It 
deserves mention that, on the whole, the Treaty of Rome's colonial scheme was established without any prior consideration as to the opinions from within the territories to be subjected to incorporation or association (Heywood 1981: 210; Lynch 1997: 204).

This arrangement, whereby the other members, in particular West Germany, collectively helped finance investments in France's African colonies in exchange for access to colonial markets was, from the perspective of Paris, nothing less than a sine qua non for the preservation and anticipated animation of its imperial enterprise in Africa, its Union française (the French Union) (see further Bossuat 1996: 320-355; Guillen 1992; Kent 1992; Lynch 1997; Migani 2008: 49-62; Muller 2000).

If the Dutch government was the most opposed to the EEC's association scheme due, inter alia, to its fear of high costs and divergent views on trade policy, but also because of its reluctance of getting mixed up in France and Belgium's colonial projects and problems (Laurent 1972: 214; Lynch 1997: 204) - sentiments in West Germany were a bit more mixed (Lynch 1997: 204). Within Adenauer's Cabinet some important figures (among them the minister of economy, Ludwig Erhard) were vehemently against it and the social democratic opposition made it clear that if it was to endorse the Rome Treaty 'Germany should assume no responsibility for the colonial policies of the countries whose overseas territories were to be under EEC' (Haas 1958: 139, n48). This notwithstanding, Adenauer's clout and determination not to spoil an unprecedented opportunity for closer European integration carried the day, and he had, we should add, the majority within his Cabinet firmly on his side. 
Adenauer's personal outlook was thus much in line with the general perspective from which Paris and other actors derived their plans for Eurafrican integration. Adenauer's motivation for European integration was primarily political and geopolitical; and it was a geopolitics to no little extent inspired by Coudenhove-Kalergi's interwar Pan-European movement (Schwartz 1997: 237-8). Adenauer not only believed in the 'superiority of Western civilization'; he was equally convinced of the inherent racial inferiority of blacks. It was, therefore, inconceivable, as Adenauer phrased it, 'that Africa, as a black continent, could be independent alongside the other continents' (quoted in Schwartz 1997: 191). He also firmly believed that '[t]he domination of the Mediterranean basin by the Soviet Russians would simply be the end for Europe.' (quoted in Schwartz 1997: 190) To prevent this from happening, Adenauer deemed it necessary for the West to embark on a massive economic development of the southern Mediterranean and the adjacent Middle East, so as to fully incorporate these regions into Western Europe's sphere of interests (Schwartz 1997: 190-1; 373).

During the Suez crisis Adenauer's European conviction would be strengthened further. As the unfolding world events were seen as posing a challenge to Europe's influence in global affairs, it had become all the more important for Europe to stake out its common geopolitical interests in a more independent fashion. 'Then, just as Coudenhove-Kalergi had said in his time', Hans-Peter Schwartz (1997: 238) notes, 'Adenauer spoke of the "appearance of non-white peoples on the political stage of world events"'. This, and its potential effects on the future constitution of the UN, Adenauer found to be deeply disturbing (Schwartz 1997: 254-5). 
Adenauer's conviction concerning the need for a strong European power, built on a solid French-German partnership and more independent from the US, thus happened to solidify together with France's decision to make the realization of the EEC hinge on Eurafrica. The utterly humiliating conclusion of the Suez crisis - where the US and the Soviet Union flexed their superior power and forced Britain and France to withdraw from Egypt, thus dealing a heavy blow to French and British interests and international prestige - would just add further impetus to both France's (Marjolin 1989: 297) and Adenauer's objectives. The dishonourable ending of the Suez campaign coincided with a high-level French-German meeting in Paris to sort out the final obstacles in the EEC negotiations. As Mollet had hung up the phone with the British premier Anthony Eden, having failed to persuade him to defy US pressure and prolong the Suez operation just a bit longer, Adenauer - a wholehearted supporter of the Suez war - decided to comfort Mollet, telling him:

France and England will never be powers comparable to the United States and the Soviet Union. Nor Germany either. There remains to them only one way of playing a decisive role in the world; that is to unite to make Europe. England is not ripe for it but the affair of Suez will help to prepare her spirits for it. We have no time to waste: Europe will be your revenge. (quoted in Kyle 2003: 467; see also Bossuat 1996: 335)

As The Economist (1957) wrote in January 1957, two months prior to the signing of the Rome Treaty: 'since the Suez adventure, [European] integration schemes, far from being suspected as "American plots," have a third force halo.' At its meeting in Stresa, 
Italy, in September 1956, the Liberal International rallied around a 'United Europe', seeing it as the only potent antidote to figures such as President Nasser of Egypt (Hoffman 1956). 'The efforts of Arab-Asian nationalists to oust Europeans', The New York Times reported, 'are seen by many liberals as the newest and most challenging reason for accelerating West European unity' (Hoffman 1956). If Europe was united, the president of the Liberal International, Roger Motz, asked rhetorically, 'Would Colonel Nasser have dared nationalize the Suez Canal, would the Algerian rebels have thought of gaining something by taking up arms?' (quoted in Hoffman 1956). These strong sentiments provided, it should come as no surprise that Louis Armand - a close aid to Monnet and the first president of the European Atomic Energy Community during the ceremony following upon the signing of the Treaty of Rome on March 25, 1957, went as far as suggesting (in jest) that 'We ought to erect a statue to Nasser'; 'To the federator of Europe' (quoted in Bromberger and Bromberger 1969: 176).

As should have become obvious from our account so far, Eurafrica cannot be reduced to a simple auxiliary to the Cold War and the efforts to contain the spread of Communism in Africa. To a significant extent, of course, it did form part of that too. But, and to apply Matthew Connelly's (2000; 2002) astute idea of 'taking off the Cold war lens', Eurafrica must also be construed as a strategy of containment in its own right, targeting various anti-colonial and anti-Western movements that were growing in the Southern hemisphere and which were not, by far, reducible to Moscow puppets: i.e. Pan-Africanism, pan-Arabism and pan-Islamism. Thus wrote Guy Mollet to Anthony Eden in March 1956: 
The present period will be decisive for the future of the world. After having contained the offensive of pan-Slavism, the West must now confront that of panIslamism, which conspires with Soviet pan-Slavism. Colonel Nasser, in his writings, has made his objective known: to recreate the empire of Islam around Egypt... There is only one game which is being played out in the Near East as in North Africa: that of the expansion of pan-Islamism. (quoted in Connelly 2002: 91)

Alongside European integration's embeddedness in the Cold War logic, the political actors, intellectuals and institutions who shaped the content and direction of European integration also saw it as deeply entrenched in a North-South struggle, and thus as a response to an allegedly deepening conflict between Christian and Muslim civilizations, between universal values and jihad and between the white European race, on the one side, and the 'hordes' of brown, black and yellow races on the other (Connelly 2000; 2002).

But European integrationists' approach to Africa was often also marked by strong reformist, progressive and accommodating currents, particularly from the mid-1950s onwards. Economic development and Eurafrican 'interdependence', not exploitation and colonialism, were keywords here. As seen above, when referring to both Dutch and German hesitations towards the incorporation of colonial responsibilities within the EEC structure, this reflected a growing concern from within Western Europe not to be branded as reactionary colonialists, but rather as pioneers of African development and modernization. In the complex, contradictory and undecided terrain of the late 1950s, this was thus yet another strategy of responding to the 'appearance of non-white 
peoples on the political stage of world events', to the changing mood within the UN organization, to the spirit of the Afro-Asian Bandung Conference (held in 1955) and the non-aligned movement. In this situation, the EEC's Eurafrican system of colonial association becomes, from a European perspective, the solution to the problem of accepting the increasing autonomy or self-government of the colonies, while at the same time continuing to gain from them economically and strategically. Thus, EEC association is articulated as an offer to African colonies of a modern and mutually beneficial partnership. In this context independence gets framed as outmoded and harmful for the African territories. According to Mollet, 'Isolated nations can no longer keep pace with the world. What would Algeria amount to by itself? On the other hand, what future might it not have, as one of the foundations of the Eurafrican community now taking shape.' 'Independence', Mollet affirmed, 'would result in inevitable economic and social regression as well as political regression toward dictatorship or the quasi-feudal regime of certain Arab States - would this be progress?'. Instead of moribund independence and national sovereignty, Mollet concluded, 'interdependence among nations is becoming the rule' (File: EN-2736, 9 January 1957, Mollet, HAEU).

In this context, too, the Eurafrican offer of EEC association may be interpreted as a divide and rule scheme, whereby the alleged African benefits of EEC association would thwart the Pan-African movement (Martin 1982), attracting its moderates and isolating its radical and most committed leaders: foremost Ghana's Kwame Nkrumah and 
Guinea's Séko Touré. ${ }^{4}$ As Nkrumah's had it, the Treaty of Rome and the EEC marked 'the advent of neo-colonialism in Africa' (quoted in Martin 1982: 229), whereby association represented a newfangled arrangement for 'collective colonialism which will be stronger and more dangerous than the old evils we are striving to liquidate' (quoted in Asante 1993: 740). More specifically, leaders such as Nkrumah and Touré saw the EEC's Eurafrican design not only as a strategy to foil national independence in Africa per se; more importantly perhaps, they also saw it as a deliberate attempt to frustrate the formation of any types of independently organized African integration and regionalisation schemes.

Given the high stakes involved in the EEC's and France's Eurafrican bid, combined with the mixed African reception, there was much work to be done on the international scene in order to persuade and reassure the world about the great boons of Eurafrican integration. This is borne out by the rich international media coverage that Eurafrica received during the latter part of the 1950s. Right after an agreement on the EEC's Eurafrican integration had been reached (in February 1957), Guy Mollet went on a state visit to the US, which, upon scrutiny of Mollet's public speeches and press conferences, would amount to a veritable Eurafrican promotion tour, the premier seemingly never missing an opportunity to emphasize that European integration was as much about Eurafrican integration. As Mollet said before the US Senate, Europe's 'economic development will bring about a better standard of living to the European as well as to the African peoples freely [sic!] associated to her. This is not a hazy dream. I

\footnotetext{
${ }^{4}$ That this indeed was the case is amply illustrated in Arnold Rivkin's (at the time Development Advisor to the World Bank) enthusiastic account (from 1966) of the EEC's 'fruitful' Eurafrican association scheme.
} 
am firmly convinced that EURAFRICA will be the reality of tomorrow.' (File: EN-2737, 27 February 1957, Mollet, HAEU)

Two weeks before the EEC's Eurafrican agreement had been sealed, the French foreign minister Christian Pineau laid out the plans for Eurafrica before the UN General Assembly's Political Committee. 'Europe in its entirety', he argued, 'bringing to Africa its capital and its techniques, should enable the immense African continent to become an essential factor in world politics'. Linking Eurafrica to the Algerian crisis, Pineau cautioned that an estranged Algeria would 'be pledged to fanaticism and by its very poverty, open to communism'. By contrast, he went on, 'its participation in Eurafrica would mean for Algeria comfort, riches - in other words, the true condition of independence' (quoted in James 1957). Pineau's address chimed very well with the outlook of The New York Times, whose subsequent editorial did its utmost to convince the world about the merits of Eurafrica; let us therefore quote at some length:

The voice of the civilizing France of long history was heard in the United Nations on Monday. Foreign Minister Pineau's presentation of France's Algerian case was a reminder that the world as a whole owes much to the French and that in these tormented days of political and nationalistic strife there are perennial values in the ideals of France, Britain and the West in general (we would like to include our own American mission) that should not be beaten down in the current rage against so-called colonialism. [...] The oversimplification of the case by the ArabAsian bloc, supported by the Soviet group, has impressed and fooled many millions of well-meaning people around the world. [...] What was especially challenging and hopeful in M. Pineau's presentation to the General Assembly was his vision of a broader European-African community, based on common cultural, 
economic and strategic interests. [...] 'Europe in its entirety,' said M. Pineau, 'bringing to Africa its capital and its techniques, should enable the immense African continent to become an essential factor in world politics.' So it should; so it should. 'Eurafrica,' as he called it, can only be a dream today, but it is the sort of dream that other Frenchmen, like Jean Monnet, have envisaged for Europe herself and have done much to foster. It is the sort of dream that can become reality and that, perhaps, must become reality if the world is to avoid another and greater holocaust. (The New York Times 1957)

\section{Conclusion}

In June 1960, German daily Die Welt carried the headline 'Is Africa running away from the EEC'. The article asserted that at the time when the Treaty of Rome was drafted, 'the fact that Europe would be faced by independent States in Africa within only a few years could scarcely have been anticipated.' Such independence, the author warned, risked upsetting the EEC's entire edifice of African association. Lest a new EEC strategy towards Africa was promptly launched, the article concluded, the situation could soon prove 'dangerous for Europe and hence for the West in its entirety' (Himpele 1960). When in 1963 eighteen independent African states decided to retain multilateral EEC association under the Yaoundé Convention, any such fears were, of course, put to rest; by the mid-1970s most African states had opted for EEC association through Yaoundé's successor, the Lomé Convention (today replaced by the Cotonou Agreement). More plausible though, is Die Welt's judgement that the Rome Treaty was negotiated under the assumption that most African territories would remain European dependencies or 
colonies for the foreseeable future. If proven to be true - yet more research is needed here - this hypothesis may partly explain why the 1950s' confident Eurafrican project would peter out in the 1960 s - although never disappearing. While neo-colonial dependency and clientelism, which were to characterize the post-independence relations between the EEC and many African states (se e.g. Martin 1982; Shaw 1979), certainly harmonized with some of the Eurafrican objectives, such relations nonetheless fell far short of sustaining the Eurafrican zeal of the 1950s. The reason for this may precisely be that the conception of Eurafrica always presupposed a Europe more or less in full control of the African scene. To put it differently, Eurafrica demanded colonial relations and proved ill-equipped for even modest forms of African agency and sovereignty offered under neo-colonial relations. With independence facilitating Africa's full conversion into a battleground of the Cold War this also eclipsed any real prospects of having Western Europe evolve into a relatively independent third force in global geopolitics. Provided that Eurafrica in so many ways was tantamount to 'third force Europe', this should also explain the rather sudden decline of Eurafrica during the 1960s.

In many ways, then, the study of the rise and decline of Eurafrica in the postwar period becomes a study of the Cold War logic and ideology's rise to dominance. However, and in line with Connelly's argument above, the only way to conceive of this is precisely by decentering the Cold War as the dominant analytical framework. Otherwise the rich material pointing to alternative driving forces behind European integration becomes incomprehensible to us. Also, the radically different geopolitical 
designs for the postwar world order that was encoded in the idea of Eurafrica will then remain at best a peculiar historical anecdote, unworthy of further consideration. As we have shown, Eurafrica was far more than that.

We have traced the contours of a political, intellectual and academic discourse that played a considerable role in the debates on European integration and its institutional formation in the inter- and postwar periods. According to this discourse, a future European community was inseparable from a common and unified colonization of Africa. There is strong evidence to support that these ideas were instrumental in the actual, diplomatic and political constitution of the EU, or of Europe as a political subject, although we must save the detailed demonstration of this for a later time. If our thesis is true, the origins of the EU cannot be separated from the perceived necessity to preserve and prolong the colonial system. We all know that the inequality that obtains still today between Europe and Africa has a history; but few have explored the role that the EU - and European integration more generally - has played in it. And the essentials remain as they were then: at least on the political level. Just as selfevident that the EU should feel free to do as it pleases to prevent African migrants from entering Europe, just as self-evident it is that the EU feels the right to enter Africa. Let us finish, then, with a more contemporary reference. Speaking in Dakar in 2007, French President Nicholas Sarkozy demonstrated that Eurafrica still remains, in the visions of the most high-ranking European politicians, the manifest destiny of two continents: 'What France wants with Africa is co-development, shared development ... What France wants with Africa is to prepare the advent of "Eurafrica", a great common 
destiny which awaits Europe and Africa.' If Africa re-emerged as a key sphere in the geopolitics of Eurafrica and the Cold War in the 1950s, it is now re-emerging as a key space of interest in the geopolitics of globalization, with the EU, China, the US and others scrambling for control over Africa's vast natural resources and emerging markets.

\section{Acknowledgement}

We would like to express our gratitude to the staff at the Historical Archives of the European Union in Florence for their generous assistance. The research for this paper was made possible by a grant from the Swedish Research Council.

\section{Archival material:}

The Historical Archives of the European Union (HAEU), European University Institute, Florence

\section{Material consulted:}

EN-Emile Noël; EN.01-Activitiés européennes avant 1958; EN.01-04.01-Discours de Guy Mollet 1956-58:

- File: EN-2736, 'Text of the French government's statement on Algeria issued by Premier Guy Mollet', 9 January 1957.

- File: EN-2737, 'Statement given by French Premier Guy Mollet on his arrival at the Washington Airport', 25 February 1957.

- File: EN-2737, 'Address by Mr. Guy Mollet, President of the Council of Ministers of the Republic of France before the Senate of the United States Washington', 27 February 1957.

\section{References}

Ageron, C-R. (1975) 'L'Idée d'Eurafrique et le débat colonial franco-allemande de l'entre-deuxguerres', Revue d'histoire contemporaine et moderne July-September: 446-475.

Asante, S.K.B (1993) 'Pan-Africanism and regional integration', in Ali A. Mazrui (ed.) General history of Africa VIII: Africa since 1935, Oxford: Heinemann, pp. 724-43.

Bossuat, Gérard (1996) L'Europe des français 1943-1959: La IVe république aux sources de I'Europe communautaire, Paris: Publications de la Sorbonne. 
Bromberger, Merry and Bromberger, Serge (1969) Jean Monnet and the United States of Europe, New York: Coward-McCann.

Connelly, Matthew (2000) 'Taking Off the Cold war Lens: Visions of North-South Conflict during the Algerian War for Independence', American Historical Review 105 (3): 739-69.

Connelly, Matthew (2002) A Diplomatic Revolution: Algeria's Fight for Independence and the Origins of the Post-Cold War Era, New York: Oxford University Press.

Coudenhove-Kalergi, Richard N. ([1923] 1926) Paneuropa ( $2^{\text {nd }}$ edition), Wien \& Leipzig: Paneuropa-Verlag.

Coudenhove-Kalergi, Richard N. (1929) 'Afrika', Paneuropa 5 (2).

Coudenhove-Kalergi, Richard N. (1932) 'Reparationen und Kolonien', Paneuropa 8 (1).

CE (Council of Europe) (1952) The Strasbourg Plan, Strasbourg: Secretariat-General Council of Europe.

Deighton, Anne (2006) 'Entente Neo-Coloniale?: Ernest Bevin and the Proposals for AngoFrench Third World Power, 1945-1949', Diplomacy and Statecraft 17: 835-52.

Ebert, Friedrich (1926) Schriften, Aufzeichnungen, Reden, vol. 2, Darmstadt.

European Union (2009a) 'Declaration of 9 May 1950', Europa (official website of the European Union), http://europa.eu/abc/symbols/9-may/decl_en.htm.

European Union (2009b) 'What is Europe Day?', Europa (official website of the European Union)http://europa.eu/abc/symbols/9-may/euday_en.htm.

Gilbert, Mark (2008) 'Narrating the Process: Questioning the Progressive Story of European Integration', Journal of Common Market Studies 46 (3): 641-62.

Guernier, Eugène L. (1933) L'Afrique: Champ d'expansion de l'Europe, Paris: Armand Colin.

Guillen, Pierre (1992) 'Europe as a Cure of French Impotence? The Guy Mollet Government and the Negotiation of the Treaties of Rome', in Ennio Di Nolfo (ed.) Power in Europe? II: Great Britain, France, Germany and Italy and the Origins of the EEC 1952-1957, Berlin: Walter de Gruyter, pp. 505-16.

Haas, Ernst B. (1958) The Uniting of Europe: Political, Social, and Economic Forces 1950-1957, Notre Dame: University of Notre Dame Press.

Heywood, Robert W. (1981) 'West European Community and the Eurafrica Concept in the 1950s', Journal of European Integration 4 (2): 199-210. 
Hick, Alan (1991a) 'The "European Movement"', in Walter Lipgens (ed.) Documents on the History of European Integration, Vol. 4, Berlin: Walter de Gruyter, pp. 319-435.

Hick, Alan (1991b) 'The European Union of Federalists', in Walter Lipgens (ed.) Documents on the History of European Integration, Vol. 4, Berlin: Walter de Gruyter, pp. 8-111.

Himpele, Ferdinand (1960) 'Läuft Afrika der EWG davon?', Die Welt, 2 June. (Translated by European Navigator; retrieved 10 December 2009 from http://www.ena.lu/africa-runningaway-eec-die-welt-june-1960-020200670.html.)

Hoffman, Michael L. (1956) 'World Liberals See a United Europe As the Best Answer to Nasser's Moves', The New York Times, 14 September.

Hurd, Volney D. (1957) 'Eurafrica Reechoes', The Christian Science Monitor, 21 March.

James, Michael (1957) 'France Proposes New Plan to Link Africa to Europe', The New York Times, 5 February.

Kent, John (1992) The Internationalization of Colonialism: Britain, France, and Black Africa, 1939-1956, Oxford: Clarendon Press.

Koller, Cristian (2001) 'Von Wilden aller Rassen niedergemetzelt': Die Diskussion um die Verwendung von Kolonialtruppen in Europa zwischen Rassismus, Kolonial- und Militärpolitik (1914-1930), Stuttgart: Franz Steiner Verlag.

Kyle, Keith (2003) Suez: Britain's End of Empire in the Middle East, London: I. B. Tauris.

Laurent, Pierre-Henri (1972) 'The Diplomacy of the Rome Treaty, 1956-57', Journal of Contemporary History 7 (3/4): 209-20.

Lipgens, Walter (1982) A History of European Integration, vol. 1, Oxford: Clarendon Press.

Lusane, Clarence (2003) Hitler's Black Victims, New York: Routledge.

Lynch, Frances M. B. (1997) France and the International Economy: From Vichy to the Treaty of Rome, London: Routledge.

Marjolin, Robert (1989) Architect of European Unity: Memoirs 1911-1986, London: Weidenfeld and Nicolson.

Martin, Guy (1982) 'Africa and the Ideology of Eurafrica: Neo-Colonialism or Pan-Africanism?', The Journal of Modern African Studies 20 (2): 221-38.

McKay, Vernon (1963) Africa in World Politics, New York: Harper \& Row.

Morton, Patricia A. (2000) Hybrid Modernities: Architecture and Representation at the 1931 Colonial Exposition, Paris, Cambridge, Mass.: The MIT Press. 
Moser, Thomas (2000) Europäische Integration, Dekolonisation, Eurafrika: eine historische Analyse über Entstehungsbedingungen der Eurafrikanischen Gemeinschaft von der Weltwirtschaftskrise bis zum Jaunde-Vertrag, 1929 - 1963, Baden-Baden: Nomos Universitätsschriften.

Muller, Karis (2000) 'The Birth and Death of Eurafrica', International Journal of Francophone Studies 3 (1): 4-17.

Migani, Guia (2008) La France et L'Afrique sub-saharienne, 1957-1963: Histoire d'une décolonisation entre idéaux eurafricains et politique de puissance, Brussels: Peter Lang.

Nelson, Keith L. (1970) 'The "Black Horror on the Rhine": Race as a Factor in Post-World War I Diplomacy', The Journal of Modern History 42 (4): 606-27.

Palayret, Jean-Marie (2005) 'Les mouvements proeuropéens et la question de l'Eurafrique, du Congrès de La Haye à la Convention de Yaoundé (1948-1963)', in Marie-Thérèse Bitsch and Gérard Bossuat (eds.) L'Europe unie et l'Afrique: de l'idée d'eurafrique à la convention de Lomé I, Brussels: Bruylant, pp. 185-229.

Rivkin, Arnold (1966) 'Africa and the European Common Market: A Perspective', Monograph Series in World Affairs 3 (4), Denver: University of Denver.

Schwartz, Hans-Peter (1995) Konrad Adenauer: A German Politician and Statesman in a Period of War, Revolution and Reconstruction, Vol. 1: From the German Empire to the Federal Republic, 1876-1952, Oxford: Berghahn Books.

Schwartz, Hans-Peter (1997) Konrad Adenauer: A German Politician and Statesman in a Period of War, Revolution and Reconstruction, Vol. 2: The Statesman, 1952-1967, Oxford: Berghahn Books.

Shaw, Timothy M. (1979) 'EEC-ACP Interactions and Images as Redefinitions of Eurafrica: Exemplary, Exclusive and/or Exploitative?', Journal of Common Market Studies 18 (2): 135-58.

Sörgel, Herman (1932) Atlantropa, Munich: Piloty and Loehle; Zürich: Fretz and Wasmuth.

The Economist (1957) 'M. Mollet Pleads for Europe', 26 January.

The New York Times (1957) 'Europe and Africa' (editorial), 6 February.

Theweleit, Klaus (2000) Männerphantasien, vol. 1, Frauen, Fluten, Körper, Geschichte. 2d ed. Munich \& Zürich: Piper Verlag.

Treaty establishing the European Economic Community (1957) Rome, 25 March.

Wigger, Iris (2010) "'Black Shame"' - the campaign against "racial degeneration" and female degradation in interwar Europe, Race \& Class 51 (3): 33-46. 
Zischka, Anton (1951) Afrika: Europas Gemeinschaftsaufgabe Nr. 1, Oldenburg: Gerhard Stalling Verlag. 